\title{
Pepsinogen A Measurement
}

National Cancer Institute

\section{Source}

National Cancer Institute. Pepsinogen A Measurement. NCI Thesaurus. Code C100469.

The determination of the amount of pepsinogen A present in a sample. 